\title{
Characterization and quantification of tumor infiltrating lymphocytes in breast cancer
}

\author{
Shahinaz Bedri ${ }^{*}$, Mahmoud Mohamed ${ }^{2}$, Hina Sarwath ${ }^{1}$, Konduru Sastry ${ }^{1}$ \\ From Updates on Immunotherapy of Cancer and Immunoscore Symposium, part of the Sidra Symposia Series, \\ held in partnership with the Society for Immunotherapy of Cancer \\ Doha, Qatar. 22-23 January 2014
}

\section{Background}

Tumor infiltrating lymphocytes (TILs) are a significant component of the tumor microenvironment [1]. In breast cancer the prognostic and predictive value of TIL is under active investigation [2]. The goal of our study was to define specific TIL subtypes and regional quantification in breast cancer of patients from the MENA region.

\section{Methodology}

47 FFPE samples with known clinic-pathological data were selected and studied using immunohistochemistry technique. TIL immune markers studied were CD3, CD8, CD45RO and FOXP3 and quantified by modified $\mathrm{H}$-score system. Results were analyzed via SPSS.

\section{Results}

A positive correlation between CD3 and CD8 expression ( $\mathrm{rs}=0.614, \mathrm{n}=24, \mathrm{P} 0.001)$ and $\mathrm{CD} 3$ and CD45RO expression ( $\mathrm{rs}=0.621, \mathrm{n}=24, \mathrm{P}$ 0.001) were noted in the center of the tumor (CT).CD3 median percentage in CT was higher in grade 2 and grade 3 breast carcinoma compared to grade 1 (P 0.023). CD3 in the center of the tumor and CD8 in the invasive margins (IM) were significantly higher in ER/PR negative Her2/neu positive tumors compared to triple negative breast cancers. Lower CD3, CD8 and FOXP3 percentages were noticed in TNBC tumors. CD45RO median percentage was shown to be higher in the IM region.

\section{Conclusion}

TIL were affected by the patient clinic-pathological characteristics.

'Department of Research, Weill Cornell Medical College in Qatar, Doha, Qatar

Full list of author information is available at the end of the article

\section{Authors' details}

${ }^{1}$ Department of Research, Weill Cornell Medical College in Qatar, Doha, Qatar. ${ }^{2}$ Pharmacy, Hamad Medical Corporation, Doha, Qatar.

Published: 24 February 2014

\section{References}

1. Hanahan D, Weinberg RA: Hallmarks of cancer: the next generation. Cell 2011, 144(5):646-74, doi: 10.1016/j.cell.2011.02.013. Review. PubMed PMID: 21376230

2. Mahmoud SM, Paish EC, Powe DG, Macmillan RD, Grainge MJ, Lee AH, Ellis IO, Green AR: Tumor-infiltrating CD8+ lymphocytes predict clinical outcome in breast cancer. J Clin Oncol 2011, 29(15):1949-55, doi: 10.1200/ JCO.2010.30.5037. Epub 2011 Apr 11. PubMed PMID: 21483002.

\section{doi:10.1186/2051-1426-2-S1-P9}

Cite this article as: Bedri et al:: Characterization and quantification of tumor infiltrating lymphocytes in breast cancer. Journal for ImmunoTherapy of Cancer 2014 2(Suppl 1):P9.
Submit your next manuscript to BioMed Central and take full advantage of:

- Convenient online submission

- Thorough peer review

- No space constraints or color figure charges

- Immediate publication on acceptance

- Inclusion in PubMed, CAS, Scopus and Google Scholar

- Research which is freely available for redistribution
C Biomed Central

\section{Biomed Central}

